\title{
Loop-Mediated Isothermal Amplification for the Detection of Tylenchulus semipenetrans in Soil
}

Borong Lin, Honghong Wang, and Kan Zhuo, Laboratory of Plant Nematology, South China Agricultural University, Guangzhou 510642, China; and Guangdong Province Key Laboratory of Microbial Signals and Disease Control, South China Agricultural University, Guangzhou 510642, China; and Jinling Liao, Laboratory of Plant Nematology and Guangdong Province Key Laboratory of Microbial Signals and Disease Control, South China Agricultural University; and Guangdong Vocational College of Ecological Engineering, Guangzhou 510520, China

\begin{abstract}
Lin, B., Wang, H., Zhuo, K., and Liao, J. 2016. Loop-mediated isothermal amplification for the detection of Tylenchulus semipenetrans in soil. Plant Dis. 100:877-883.

Tylenchulus semipenetrans is an economically important plant-parasitic nematode occurring in all citrus-producing regions of the world and causing a disease called "slow decline". For the rapid detection of this nematode, a loop-mediated isothermal amplification (LAMP) assay was developed, based on the ribosomal DNA internal transcribed spacer sequence. The optimal condition for the LAMP assay was $65^{\circ} \mathrm{C}$ for $50 \mathrm{~min}$. The LAMP products were confirmed using conventional polymerase chain reaction (PCR) and restriction analysis with the BamHI enzyme, and by adding SYBR Green I to the LAMP products for visual inspection. The LAMP assay was highly specific for the detection of

T. semipenetrans populations from different geographical origins. It was also sensitive, detecting a tenth of the DNA from an individual specimen of T. semipenetrans, which was 10 times more sensitive than conventional PCR. The LAMP protocol was applied to natural citrus rhizosphere soil samples from several orchards in China and the results were fast, sensitive, robust, and accurate. This study is the first to provide a diagnostic tool for $T$. semipenetrans using DNA extracted directly from citrus rhizosphere soils. This LAMP assay could be used as a practical molecular tool to identify $T$. semipenetrans and diagnose slow decline disease, even in remote locations.
\end{abstract}

The plant-parasitic nematode Tylenchulus semipenetrans Cobb 1913 is highly pathogenic to citrus and causes "slow decline" disease. Crop loss caused by T. semipenetrans can reach 15 to $30 \%$ annually (Duncan 2005). This nematode occurs in all citrus-producing regions of the world. In the major citrus-producing regions, infestation rates by this nematode are high. In the United States, 50 to $90 \%$ of the citrus orchards in Arizona, California, Florida, and Texas are infested by this nematode (Duncan 2005; Heald and O'Bannon 1987). In Spain and Brazil, the nematode infests 70 to $90 \%$ of commercial citrus orchards (Van Gundy and Meagher 1977). In China, T. semipenetrans is found in most citrus-producing areas, including Guangdong, Guangxi, Sichuang, Yunnan, and Hunan Provinces (Zhao and Yang 2006). In some citrus orchards within Guangxi and Yunnan Provinces, more than $90 \%$ of the citrus trees are infested with T. semipenetrans (Huang et al. 2011; Li et al. 2001).

To appropriately manage slow decline, the first task is to diagnose the disease correctly. However, the aboveground symptoms of slow decline are similar to other root diseases and nutrient deficiencies, including stunting, slow growth, yellowing, and reduced foliage, fruit size, and yield. This makes it difficult to correctly diagnosis (Duncan 2005). In China, some citrus orchards infested with $T$. semipenetrans have been misdiagnosed as citrus huanglongbing and destroyed (Huang et al. 2012). To date, the sampling, manual extraction, and identification of $T$. semipenetrans from citrus rhizosphere soil is the only method available to correctly diagnose slow decline (Verdejo-Lucas and Kaplan 2002). Currently, diagnostics rely on the extraction of second-stage juveniles (J2) of T. semipenetrans

Corresponding author: K. Zhuo; E-mail: zhuokan@scau.edu.cn

Accepted for publication 4 December 2015.

http://dx.doi.org/10.1094/PDIS-07-15-0801-RE

(C) 2016 The American Phytopathological Society from soil. For the observer who lacks skills and training, it is very difficult to correctly identify $T$. semipenetrans based on the morphology of only $\mathrm{J} 2$ specimens. In particular, $T$. semipenetrans $\mathrm{J} 2$ specimens can easily be misidentified as Meloidogyne spp. from citrus rhizosphere soils.

In the past decade, methods that utilize the polymerase chain reaction (PCR) have been developed to identify plant-parasitic nematodes based on various target sequences, mainly through the amplification of ribosomal DNA (rDNA) or mitochondrial DNA (mtDNA) sequences (Adam et al. 2007; Blok et al. 2002; Yan et al. 2013). Increasingly, studies have demonstrated the effectiveness of identifying and differentiating nematodes using molecular techniques. At present, several molecular techniques have been developed to identify $T$. semipenetrans, including rDNA-internal transcribed spacer region (ITS) PCR restriction fragment length polymorphism (RFLP) (Maafi et al. 2012; Park et al. 2009; Wang et al. 2004) and PCR amplification using species-specific primers derived from the rDNA-ITS (Liu et al. 2011; Maafi et al. 2012). In contrast to the morphological methods, PCR-based methods are more sensitive and accurate for T. semipenetrans identification (Liu et al. 2011). However, for conventional PCR, an expensive thermal cycler is needed; this limits its routine use.

A relatively new DNA amplification technique, loop-mediated isothermal amplification (LAMP), was developed in 2000 (Notomi et al. 2000). During LAMP, the reaction is performed at an isothermal temperature of 60 to $65^{\circ} \mathrm{C}$, eliminating the need for expensive thermal cyclers. LAMP requires a polymerase with high-strand displacement activity, and two or three sets of primers that identify six or eight distinct regions on the target gene; these requirements strongly increase the specificity of the reaction. All LAMP steps can be done in a single tube over a short time period of 0.5 to $1 \mathrm{~h}$, and detection of the amplification product can be determined by the naked eye using intercalating dyes, such as SYBR green, propidium iodide, or ethidium bromide, or by measuring the turbidity caused by the formation of magnesium pyrophosphate (Duan et al. 
2014; Maeda et al. 2005; Mori et al. 2001; Nagamine et al. 2002; Notomi et al. 2000). Hence, compared with conventional PCR technologies, LAMP offers some major advantages, including simplicity, sensitivity, rapidity, specificity, and low cost. These factors make it well suited for field diagnosis applications.

Currently, LAMP has been successfully applied in plant pathology to detect plant pathogens, including fungi (Dai et al. 2012; Duan et al. 2014; Niessen and Vogel 2010) and bacteria (Harper et al. 2010). Only a few studies have developed LAMP detection methods for the identification of plant-parasitic nematodes (Kikuchi et al. 2009; Niu et al. 2011, 2012; Peng et al. 2012). At present, LAMP assays have been developed only for Bursaphelenchus xylophilus (Kikuchi et al. 2009), Meloidogyne spp. (Niu et al. 2011, 2012), and Radopholus similis (Peng et al. 2012). In this study, a LAMP assay for the rapid detection of $T$. semipenetrans based on its rDNA-ITS sequence was developed. The LAMP assay was evaluated by comparing it with conventional PCR methods, and by conducting tests using field citrus rhizosphere soil samples.

\section{Materials and Methods}

Nematode populations and DNA extraction. Five populations of $T$. semipenetrans collected from citrus orchards in China were used. Other nematode species were also used to verify the specificity of the primers (Table 1). These included specimens isolated from

Table 1. Tylenchulus semipenetrans and other nematodes from China used in this study to test the specificity of the loop-mediated isothermal amplification assay

\begin{tabular}{|c|c|c|c|}
\hline Species & Isolate & Host & $\begin{array}{c}\text { Geographical } \\
\text { location in China }\end{array}$ \\
\hline T. semipenetrans & Ts1 & Citrus & Dali, Yunnan \\
\hline T. semipenetrans & Ts2 & Citrus & Yangjiang, Guangdong \\
\hline T. semipenetrans & Ts3 & Citrus & Fogang, Guangdong \\
\hline T. semipenetrans & Ts4 & Citrus & Yuantan, Guangdong \\
\hline T. semipenetrans & Ts5 & Citrus & Guangzhou, Guangdong \\
\hline Aphelenchoides sp. & Apco & Citrus & Fujian, Fuzhou \\
\hline Aphelenchus sp. & Apcu & Citrus & Yangjiang, Guangdong \\
\hline Ditylenchus sp. & Di & Citrus & Nanchang, Jiangxi \\
\hline Helicotylenchus sp. & $\mathrm{He}$ & Citrus & Yuantan, Guangdong \\
\hline Meloidogyne javanica & MJ1 & Towel gourd & Shenzhen, Guangdong \\
\hline M. incognita & $\mathrm{ZCd}$ & Cucumber & Zengcheng, Guangdong \\
\hline Pratylenchus brachyurus & Fj908 & Sugarcane & Zhangzhou, Fujian \\
\hline P. coffeae & $\mathrm{PC}$ & Citrus & Yangjiang, Guangdong \\
\hline P. vulnus & JXP & Peach & Jiujiang, Jiangxi \\
\hline Paratylenchus sp. & $\mathrm{Pa}$ & Citrus & Yangjiang, Guangdong \\
\hline Radopholus similis & RS & Anthurium & Guangzhou, Guangdong \\
\hline Rotylenchulus reniformis & RR & Citrus & Yangjiang, Guangdong \\
\hline Trichodorus sp. & $\operatorname{Tr}$ & Citrus & Yuantan, Guangdong \\
\hline Caenorhabditis elegans & $\mathrm{CE}$ & $\ldots$ & Yangjiang, Guangdong \\
\hline Dorylaimidae & Do & $\ldots$ & Yongsheng, Hunan \\
\hline Iotonchus sp. & Io & $\ldots$ & Yuantan, Guangdong \\
\hline Monhysterida & Mo & $\ldots$ & Yuantan, Guangdong \\
\hline Prismatolaimus sp. & $\operatorname{Pr}$ & $\ldots$ & Yongsheng, Hunan \\
\hline Qudsianematidae & $\mathrm{Qu}$ & $\ldots$ & Yongsheng, Hunan \\
\hline Tobrilus sp. & To & $\cdots$ & Yongsheng, Hunan \\
\hline
\end{tabular}

citrus rhizosphere soils in this study (Paratylenchus sp., Rotylenchulus reniformis, Helicotylenchus sp., Pratylenchus coffeae, Aphelenchoides sp., Ditylenchus sp., Aphelenchus sp., Trichodorus sp., Prismatolaimus sp., Tobrilus sp., Caenorhabditis elegans, Iotonchus sp., Dorylaimidae, Qudsianematidae, and Monhysterida) and other nematodes that have previously been reported in citrus rhizosphere soils ( $P$. brachyurus, $P$. vulnus, Meloidogyne incognita, $M$. javanica, and Radopholus similis) (Duncan 2005). All the nematodes were identified using morphological characteristics (Abebe et al. 2006; Nickle 1991) in combination with molecular data. DNA was extracted from individual nematode specimens following the protocol described by Subbotin et al. (2008). The mtDNA COII/rrnL region of Meloidogyne spp. was amplified. Two rDNA fragments (i.e., partial small subunit [SSU] or ITS) of other nematodes were amplified. Primers for mtDNA COII/rrnL amplification were C2F3 (5'-GGTC AATGTTCAGAAATTTGTGG-3') and 1108 (5'-ACCTTTGACCA ATCACGCT-3') (Powers and Harris 1993). Primers for partial SSU amplification were G18SU (5'-GCTTGTCTCAAAGATTAAGCC$\left.3^{\prime}\right)$ and R18Tyl1 (5'-GGTCCAAGAATTTCACCTCTC-3') (Chizhov et al. 2006). Primers for ITS amplification were TW81 (5'-GTTT CCGTAGGTGAACCTGC-3') and AB28 (5'-ATATGCTTAAGT TCAGCGGGT-3') (Subbotin et al. 2000). Detailed protocols of PCR amplification were as described by Maafi et al. (2003).

Primer design. Sequences of the rDNA-ITS region were chosen as the candidate targets for primer design. The sequences of the target region in Tylenchulus spp., including Tylenchulus semipenetrans (JN112276), T. graminis (JN112286), T. palustris (JN112268), T. musicola (JN112281), T. furcus (JN112285), and other nematode species, including Paratylenchus sp. (KF150664), P. coffeae (EU130845), P. brachyurus (HQ641385), P. vulnus (JQ003994), M. incognita (LC030364), Heterodera avenae (HQ450302), Aphelenchoides besseyi (EF371500), Aphelenchus avenae (KJ155784), C. elegans (JN636101), R. similis (FJ455832), Rotylenchulus reniformis (KP018580), Helicotylenchus digonicus (GQ906352), and Trichodorus viruliferus (KC160453), were obtained from the National Center for Biotechnology Information. A multiple sequence alignment was performed to compare the sequences, using the MegAlign program in Lasergene software (DNASTAR Inc., Madison, WI). Then, the primers TSF3 (5'-GCATCTGGCGAGT CTGTG-3'), TSB3 (5'-GCACCGAATCTGGAACTCAT-3'), TSFIP $(\mathrm{F} 1 \mathrm{c}+$ Bam $\mathrm{HI}+\mathrm{F} 2:$ 5'-CRGGTAAGAGCCGAGAAGGACAggatccG TCATACTTCCTCYGCCGCT-3'), and TSBIP (B1c+ttttt+B2: 5'TGTAACGCTGAGCGACTGTTGAtttttGCGACATGTGGAGAA GGC-3') were designed, using PrimerExplorer V4 software (Eiken Chemicals, Tokyo, Japan) (Fig. 1). All of the primers were synthesized by Invitrogen Biotech (Shanghai, China).

LAMP protocol and optimization. According to the user manual (New England Biolabs Ltd., London) and previous reports (Niu et al. 2011,2012 ), the LAMP reaction was performed in a $25-\mu 1$ volume comprising $2.5 \mu \mathrm{l}$ of the $10 \times$ isothermal amplification buffer, $3.5 \mu \mathrm{l}$ of $10 \mathrm{mM}$ dNTP, $1.5 \mu \mathrm{l}$ of $100 \mathrm{mM} \mathrm{MgSO}_{4}, 2.5 \mu \mathrm{l}$ of $10 \times$ primers $(1.6 \mu \mathrm{M}$ each for the TSFIP and TSBIP primers and $0.2 \mu \mathrm{M}$ each for the TSF3 and TSB3 outer primers), $1 \mu \mathrm{l}$ of Bst 2.0-DNA polymerase (New England Biolabs Ltd.), $4 \mu \mathrm{l}$ of $5 \mathrm{M}$ betaine (Sigma-Aldrich, St. Louis), and $1 \mu l$ of the template DNA.

To optimize the reaction temperature for the LAMP assay, the reactions were performed in a water bath (YiHeng Technical Co. Ltd.,

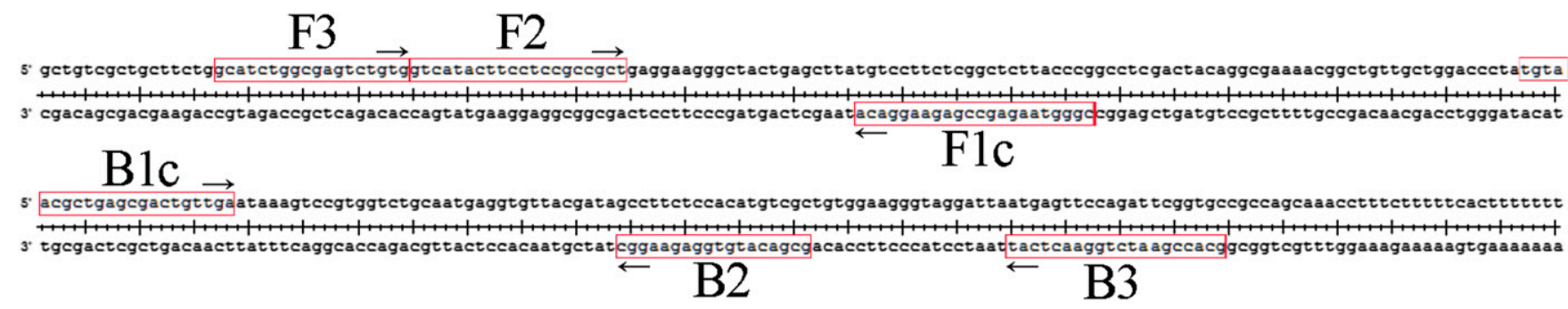

Fig. 1. Primers used in loop-mediated isothermal amplification for the detection of Tylenchulus semipenetrans. Arrows and boxes indicate the direction and location of the primers. 
Shanghai, China) at $58,60,62,63,65,67$, and $68^{\circ} \mathrm{C}$ for $90 \mathrm{~min}$. Then, the products $(10 \mu \mathrm{l})$ were separated on standard $2 \%$ agarose gels stained with Goldview (EB substitution) (Toyobo Co., Shanghai, China). A DS2000 DNA marker (Dongsheng Biotech, Shanghai, China) was used to determine the molecular size of the bands, which were photographed under UV light using an Alphalmager system (Alpha Innotech Co., San Leandro, CA). The optimal temperature was determined according to the band intensity obtained at different temperatures. The experiment was performed three times. One sample was included at each temperature at each experiment.

The reaction time was optimized by real-time PCR analysis using the TP860 system (Takara, Dalian, China): the reactions were performed at the determined optimal temperature in a $25-\mu 1$ reaction volume (as described above) and $1.5 \mu \mathrm{l}$ of 20x EVA green (Maygene, Guangzhou,

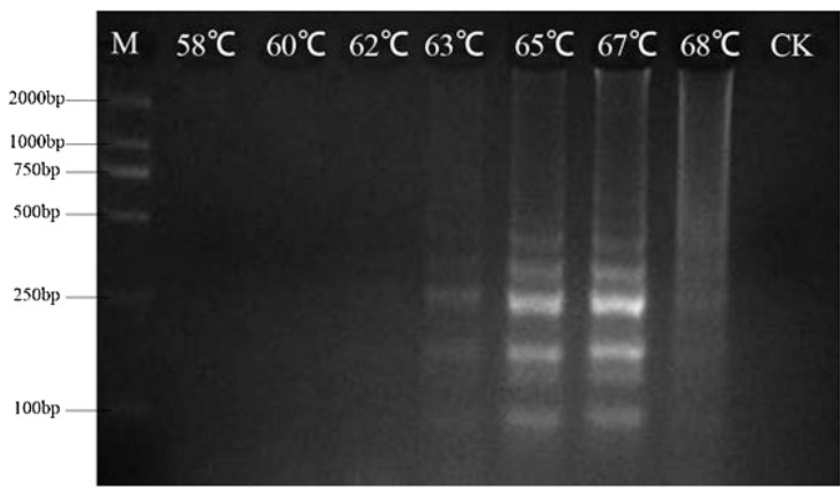

Fig. 2. Optimization of temperature requirement for the loop-mediated isothermal amplification reaction. The reaction was performed for $90 \mathrm{~min}$ at temperatures ranging from 58 to $68^{\circ} \mathrm{C}$; lane $\mathrm{M}$ represents the Ds2000 DNA molecular weight marker ladder and lane $\mathrm{CK}$ represents the control (the DNA template was replaced with $\mathrm{H}_{2} \mathrm{O}$ ).
China) was added as an intercalator. Then, 35 reaction cycles were performed for 2 min each and the signal after each cycle was determined.

LAMP specificity analysis. To determine whether the LAMP amplified the correct target sequence, the LAMP products were digested with the BamHI restriction enzyme (Thermo Fisher Scientific, Shanghai, China) and analyzed by electrophoresis. The restriction enzyme site was selected based on the appropriate sequence information (shown in the primer TSFIP). The restriction digestion system consisted of $2 \mu \mathrm{l}$ of the $10 \times$ FastDigest green buffer, $2 \mu \mathrm{l}(0.5 \mu \mathrm{g})$ of LAMP products, $1 \mu \mathrm{l}$ of BamHI, and $15 \mu l$ of double-distilled (dd) $\mathrm{H}_{2} \mathrm{O}$. The reaction was carried out at $37^{\circ} \mathrm{C}$ for $30 \mathrm{~min}$. Additionally, the PCR product generated by using the primers TSF3/TSB3 was then sequenced and the Basic Local Alignment Search Tool (BLAST) was used to examine the specificity of the primers. The PCR was performed in a $25-\mu 1$ volume, comprising $12.5 \mu$ l of the $2 \times$ EasyTaq PCR SuperMix (Transgen, Beijing), $0.5 \mu \mathrm{l}$ of primer TSF3, $0.5 \mu \mathrm{l}$ of primer TSB3, and $1 \mu l$ of the template DNA. The amplification was carried out with an initial denaturation step at $95^{\circ} \mathrm{C}$ for $3 \mathrm{~min} ; 30$ reaction cycles at $95^{\circ} \mathrm{C}$ for $10 \mathrm{~s}, 60^{\circ} \mathrm{C}$ for $30 \mathrm{~s}$, and $72^{\circ} \mathrm{C}$ for $30 \mathrm{~s}$; followed by an extension at $72^{\circ} \mathrm{C}$ for $5 \mathrm{~min}$.

To determine whether the primers were specific to Tylenchulus semipenetrans, DNA was extracted from 25 nematode populations composed of 21 different nematode species (Table 1). Each sample was loaded in triplicate and a negative control sample was also prepared, using $\mathrm{ddH}_{2} \mathrm{O}$ instead of a DNA template. The LAMP results were visually inspected with the naked eye in daylight by adding $1 \mu l$ of $1,000 \times$ SYBR Green I solution (Dingguo Biotech, Beijing) to the amplification products.

LAMP sensitivity assay for $T$. semipenetrans. DNA was first extracted from 1 or 100 individuals of T. semipenetrans. Subsequently, a 10-fold dilution of the DNA from $1 T$. semipenetrans, the DNA from 1 T. semipenetrans, 10 -fold dilution of the DNA from 100 T. semipenetrans, and the DNA from 100 T. semipenetrans were separately subjected to LAMP and conventional PCR. The LAMP assay was performed as described above, and the conventional

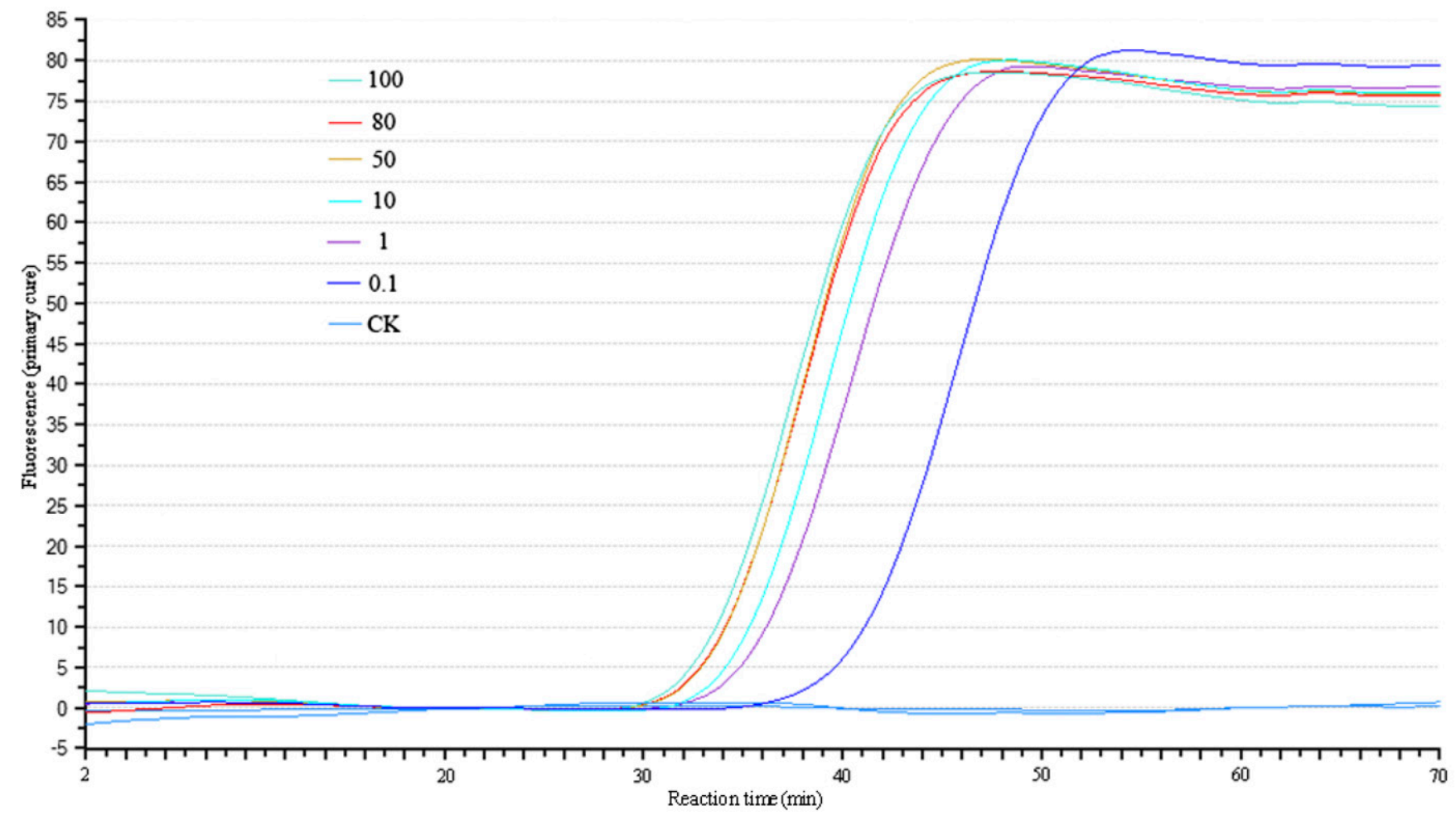

Fig. 3. Optimization of the duration of time for the loop-mediated isothermal amplification reaction. Real-time polymerase chain reaction was used to optimize the reaction time. Numbers on the $x$-axis represent the reaction time. Lines labeled $0.1,1,10,50,80$, and 100 represent 1,000-fold, 100-fold, 10-fold, 2-fold, 1.25-fold, and 1-fold dilution of the DNA template from $100 \mathrm{~T}$. semipenetrans, respectively. CK represents the control (the DNA template was replaced with double-distilled $\mathrm{H}_{2} \mathrm{O}$ ). 
PCR was conducted using the primers Ts-SF ( $5^{\prime}$-TACCAGGTT GAGCAGAGTTCTT- $\left.3^{\prime}\right)$ and Ts-SR (5'-TCCTACCCTTCCA CAGCG-3'), as described previously (Liu et al. 2011), at $95^{\circ} \mathrm{C}$ for $5 \mathrm{~min}$; then, 35 reaction cycles of $95^{\circ} \mathrm{C}$ for $45 \mathrm{~s}, 59^{\circ} \mathrm{C}$ for $30 \mathrm{~s}$, and $72{ }^{\circ} \mathrm{C}$ for $30 \mathrm{~s}$; followed by an extension period at $72^{\circ} \mathrm{C}$ for 5 min. A negative control sample was also prepared, using $\mathrm{ddH}_{2} \mathrm{O}$ instead of a DNA template. Each sample was run in triplicate and the experiment was performed three times.

Field application of LAMP. In order to evaluate the application of LAMP as a diagnostic tool for $T$. semipenetrans in the field, 24 rhizosphere soil samples from citrus orchards in different regions across China were collected. DNA was extracted from $1 \mathrm{~g}$ of soil using a PowerSoil DNA Isolation Kit and further purified with an UltraClean PCR Clean-up Kit (Mo-Bio Laboratories, Carlsbad, CA). Then, $1 \mu l$ of DNA was added into the $25 \mu l$ of LAMP reaction mixture; the LAMP reactions were performed as described above. To validate the protocol, the nematodes in each sample were also identified based on morphology. The purified DNA from T. semipenetrans was used as a positive control and $\mathrm{ddH}_{2} \mathrm{O}$ instead of the DNA of $T$. semipenetrans was used as a negative control. Three independent experiments were performed.

\section{Results}

Optimization of LAMP reaction conditions. When LAMP was conducted using T. semipenetrans DNA at 58 to $68^{\circ} \mathrm{C}$ for $90 \mathrm{~min}$, the typical ladder-like bands produced with gel electrophoresis were observed. The bands obtained were most intense at $65^{\circ} \mathrm{C}$ and no ladder-like bands were observed in the negative control (Fig. 2). The fluorescence intensity of DNA extracted from 0.1 to 100 nematodes started to increase after $30 \mathrm{~min}$ of reaction time, and reached a plateau at $50 \mathrm{~min}$ in the sample containing 0.1 nematode (Fig. 3). Therefore, the optimal condition for the LAMP assay was determined to be $65^{\circ} \mathrm{C}$ for $50 \mathrm{~min}$.

Specificity of the LAMP assay. Electrophoresis showed that the products of the LAMP assay were digested completely using the restriction enzyme BamHI (Fig. 4). In addition, the product generated using the primers TSF3/TSB3 was sequenced and the resulting 233-bp sequence was compared with known ITS sequences of $T$. semipenetrans; the sequence was $100 \%$ identical to the ITS sequences of original $T$. semipenetrans population (data not shown). The LAMP

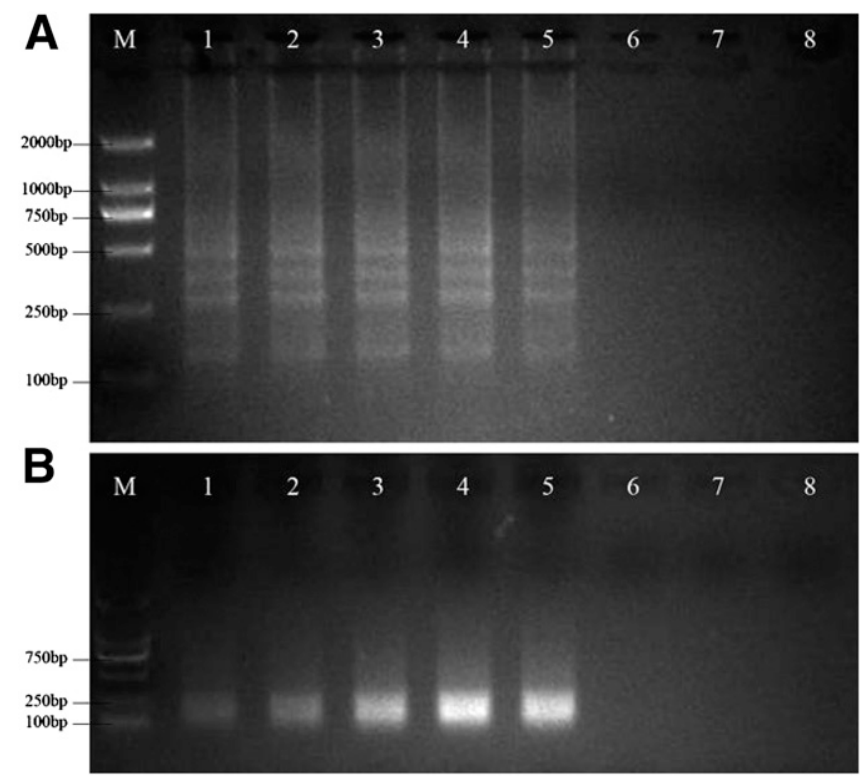

Fig. 4. Restriction enzyme analysis of the loop-mediated isothermal amplification products $\mathbf{A}$, without and $\mathbf{B}$, with $\mathrm{BamHI}$ digestion, respectively. Lane $\mathrm{M}$ represents the Ds2000 DNA molecular weight marker ladder; lanes 1 to 5 represent the DNA templates from five different isolates of Tylenchulus semipenetrans; and lanes 6 to 8 represent the DNA templates of control from Aphelenchoides sp., Aphelenchus sp., and Ditylenchus sp., respectively. assay was highly specific for $T$. semipenetrans, based on the visual evaluation with SYBR Green I using DNA isolated from $T$. semipenetrans and other nematodes found in citrus rhizosphere soil (Table 1); the $T$. semipenetrans samples resulted in positive reactions (SYBR Green I turned yellow), while the other nematode samples resulted in negative reactions (SYBR Green I remained orange to brown) (Fig. 5).

Sensitivity of the LAMP assay. The LAMP and conventional PCR assays, performed on different serial dilutions of the DNA extracted from $T$. semipenetrans, demonstrated the increased sensitivity of the LAMP assay. The conventional PCR could only detect one individual nematode but the LAMP assay could detect approximately a tenth of the DNA extracted from a single nematode (10-fold dilution of template DNA from 1 nematode; Fig. 6). This demonstrates that the LAMP assay exhibited a 10-fold greater sensitivity than conventional PCR.

Evaluation of the LAMP assay using citrus rhizosphere soil. The LAMP assay was able to detect $T$. semipenetrans, when present, in the 24 soil samples collected from the citrus orchards. Amplification occurred in 14 samples and the remaining 10 samples produced negative results. These results were confirmed by morphological observations: all of the positive samples did contain T. semipenetrans, ranging from 202 to 2,300 individuals per $100 \mathrm{~g}$ of soil. In the negative samples, although there were other nematodes, no $T$. semipenetrans specimens were isolated (Table 2).

\section{Discussion}

PCR is one of the most valuable tools for the identification of plant pathogens and plant-parasitic nematodes and diagnosis of plant

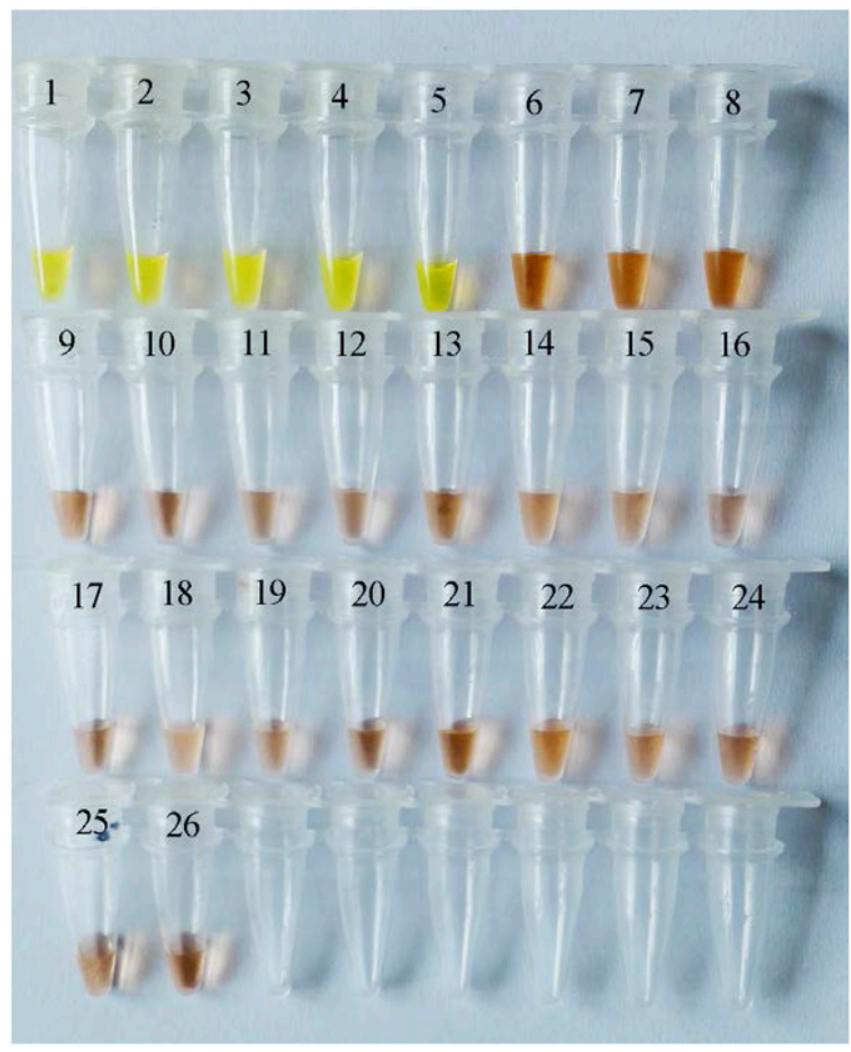

Fig. 5. Specificity of the loop-mediated isothermal amplification (LAMP) assay for Tylenchulus semipenetrans and other nematodes. SYBR Green I was added to the LAMP products from tubes 1 to $5=$ five different populations of $T$. semipenetrans; and tubes 6 to $25=$ populations of Pratylenchus brachyurus, $P$. coffeae, $P$. vulnus, Meloidogyne incognita, M. javanica, Ditylenchus sp., Aphelenchoides sp., Aphelenchus sp., Caenorhabditis elegans, Radopholus similis, Paratylenchus sp., Rotylenchulus reniformis, Helicotylenchus sp., Iotonchus sp., Trichodorus sp., Prismatolaimus sp., Tobrilus sp., Qudsianematidae, Dorylaimidae, and Monhysterida. Tube $26=$ control (the DNA template was replaced with double-distilled $\mathrm{H}_{2} \mathrm{O}$ ). 
diseases. Conventional PCR requires different temperatures to achieve amplification; therefore, an expensive thermal cycler is needed. This limits its routine use, especially in the field and in some developing countries. Other techniques of sequence-specific DNA amplification, which do not require changes in temperature during the reaction, have been developed. One of these alternative approaches is LAMP, a fast and inexpensive technique. LAMP does not require thermal cyclers and has been successfully applied to detect pathogenic microorganisms for more than 10 years (Duan et al. 2014; Fu et al. 2011). However, only in recent years has this technique been used to identify plant-parasitic nematodes. Several important plant-parasitic nematode species, including B. xylophilus, $M$. incognita, $M$. enterolobii, and $R$. similis, have been successfully identified using LAMP (Kikuchi et al. 2009; Niu et al. 2011, 2012; Peng et al. 2012). In this study, a new LAMP method was developed to detect $T$. semipenetrans. The LAMP assay was successfully applied to identify $T$. semipenetrans in crude DNA extracts from citrus rhizosphere soil.

Many studies indicate that the rDNA-ITS sequence located between the repeating array of nuclear $18 \mathrm{~S}$ and $28 \mathrm{~S}$ rDNA genes is an important marker for differentiating nematode species (Gasser and Newton 2000; Powers et al. 1997; Subbotin et al. 2001). More
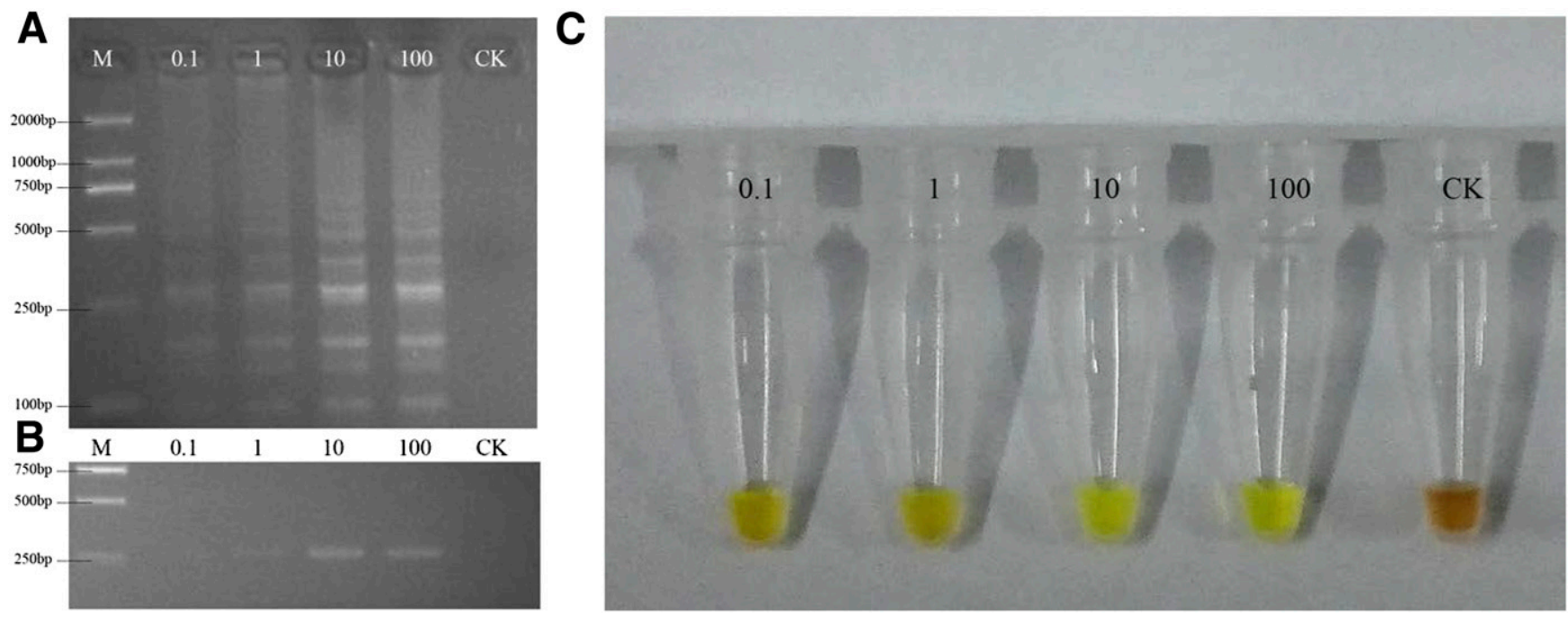

Fig. 6. Sensitivity of A, the loop-mediated isothermal amplification (LAMP) and B, conventional polymerase chain reaction methods. C, LAMP products visualized with SYBR green I using natural daylight. The initial DNA template was extracted from 1 or 100 Tylenchulus semipenetrans individuals. Lane M represents the Ds2000 DNA molecular weight marker ladder, lane 0.1 represents 10 -fold dilution of the DNA template from one $T$. semipenetrans, lane 1 represents the DNA template from one T. semipenetrans, lane 10 represents 10-fold dilution of the DNA template from $100 \mathrm{~T}$. semipenetrans, lane 100 represents the DNA template from $100 \mathrm{~T}$. semipenetrans, respectively, and CK represents the control (the DNA template was replaced with double-distilled $\mathrm{H}_{2} \mathrm{O}$ ).

Table 2. Detection of Tylenchulus semipenetrans in citrus soil samples using the loop-mediated isothermal amplification assay

\begin{tabular}{llrrr}
\hline Sample & Geographical location in China & Amplification result $^{\mathbf{a}}$ & Number of $\boldsymbol{T}$. semipenetrans $^{\mathbf{b}}$ & Other species identified $^{\mathbf{c}}$ \\
\hline 1 & Fogang, Guangdong & - & 0 & $14,16,17$ \\
2 & Fuzhou, Fujian & + & 860 & 1,13 \\
3 & Kunming, Yunnan & - & 0 & 13,14 \\
4 & Kunming, Yunnan & + & 304 & 13 \\
5 & Kunming, Yunnan & + & 0 & 13 \\
6 & Loudi, Hunan & - & 1020 & 13 \\
7 & Nanchang, Jiangxi & + & 0 & $2,4,13$ \\
8 & Nanning, Guangxi & - & 0 & 1 \\
9 & Nanning, Guangxi & - & 2300 & 2 \\
10 & Nanning, Guangxi & + & 1160 & 2,13 \\
11 & Nanning, Guangxi & + & 0 & 2,13 \\
12 & Nanning, Guangxi & - & 0 & 13 \\
13 & Yangjiang, Guangdong & - & 0 & $3,8,10$ \\
14 & Yangjiang, Guangdong & - & 0 & $2,8,9,16$ \\
15 & Yangjiang, Guangdong & - & 569 & $9,14,16$ \\
16 & Yangjiang, Guangdong & + & 482 & 3,7 \\
17 & Yangjiang, Guangdong & + & 0 & 2,3 \\
18 & Yangshan, Guangdong & - & 1000 & $2,6,13$ \\
19 & Yongsheng, Hunan & + & 550 & 1,12 \\
20 & Yongsheng, Hunan & + & 1500 & 2 \\
21 & Yongsheng, Hunan & + & 550 & 2,13 \\
22 & Yongsheng, Hunan & + & 500 & 2,12 \\
23 & Yongsheng, Hunan & + & 1100 & 11 \\
24 & Yuantan, Guangdong & + & & $7,8,16$ \\
\hline
\end{tabular}

a Symbols + and - indicate a positive and negative result, respectively.

b Morphologically identified and extracted from $100 \mathrm{~g}$ soil.

${ }^{c}$ Species 1 = Aphelenchoides sp., $2=$ Aphelenchus sp., $3=$ Caenorhabditis elegans, $4=$ Ditylenchus sp., $5=$ Dorylaimoididae, $6=$ Helicotylenchus sp. 7 = Iotonchus sp., $8=$ Monhysterida, $9=$ Paratylenchus sp., $10=$ Pratylenchus coffeae, $11=$ Prismatolaimus sp., $12=$ Qudsianematidae, $13=$ Rhabditidae, 14 = Rotylenchulus reniformis, $15=$ Tobrilus sp., $16=$ Trichodorus sp., and $17=$ Xiphenema sp. 
recently, five Tylenchulus spp., including T. semipenetrans, were distinguished and identified from their PCR-ITS-RFLP profiles, and through PCR with species-specific primers based on ITS sequences (Maafi et al. 2012). In this study, LAMP primers that targeted the ITS sequence of $T$. semipenetrans were designed. The results showed that the LAMP assay using these primers was highly specific and able to differentiate $T$. semipenetrans from other nematodes in citrus rhizosphere soils. Unfortunately, aside from $T$. semipenetrans, we were unable to obtain other Tylenchulus spp. to examine whether primers would cross-react with other species in the genus. Thus far, the genus Tylenchulus contains five valid species (T. semipenetrans, $T$. furcus, T. graminis, T. palustris, and T. musicola) (Maafi et al. 2012), of which only $T$. semipenetrans is able to infest citrus. $T$. graminis and $T$. palustris only occur in Florida and parasitize monocotyledons and non-rutaceous dicots (including Baccharis halimifolia, Fraxinus caroliniana, peach, and sea oxeye), respectively. T. furcus occurs in South Africa only, infecting monocotyledons, while T. musicola only occurs in Iran, infecting banana (Dow et al. 1990; Eisenback et al. 2007; Inserra et al. 1988, 1990; Maafi et al. 2012). Because the other species have very different host ranges and narrow distributions, the LAMP system from this study is still suitable for the detection of $T$. semipenetrans in citrus rhizosphere soils. In addition, four primers that identify six distinct regions within the ITS region of $T$. semipenetrans were used in this study, which increases the specificity of the reaction. More Tylenchulus samples could be included to validate the specificity in the future.

The validity of the LAMP assay was confirmed in 24 soil samples collected from different citrus-producing regions in China. All soil samples infested with $T$. semipenetrans were successfully detected with LAMP, whereas those without $T$. semipenetrans but with other nematodes produced negative results. There were no false-positive reactions. These results indicate that the LAMP technology is sensitive and stable, and can overcome the impact of soil substances such as humic acids, as previously reported (Niu et al. 2011, 2012).

Compared with conventional PCR (Liu et al. 2011), the LAMP assay was 10 -fold more sensitive. The results are also easier to evaluate than those from conventional PCR because they can be visualized with the naked eye using SYBR Green I staining. Moreover, the LAMP assay is rapid (50 min was found to be optimal for the detection of $T$. semipenetrans) and only requires a single constant temperature to be maintained (in this case, $65^{\circ} \mathrm{C}$ ). In other words, the developed LAMP assay provides a good alternative to conventional PCR for the rapid and simple detection of $T$. semipenetrans. LAMP can be used to detect target nematode DNA from citrus rhizosphere soils with high sensitivity and specificity. The LAMP assay developed in this study has the potential to be a useful tool for the quick detection of $T$. semipenetrans in citrus orchards and, thus, the diagnosis of slow decline disease.

\section{Acknowledgments}

This work was supported by grants from the National Key Basic Research Program of China (973 Program, numbers 2013CB127501 and 2013CB127502), the National Natural Science Foundation of China (numbers 31171824, 31471750, and 31071666), and the Special Fund for Agro-scientific Research in Public Interest of China (number 201103018). We thank M. Hu for helping to collect Meloidogyne incognita and $M$. javanica and L. Hu for helping to collect Tylenchulus semipenetrans in Yunnan Province.

\section{Literature Cited}

Abebe, E., Traunspurger, W., and Andrassy, I. 2006. Freshwater Nematodes: Ecology and Taxonomy. CABI Publishing, Cambridge, MA.

Adam, M. A. M., Phillips, M. S., and Blok, V. C. 2007. Molecular diagnostic key for identification of single juveniles of seven common and economically important species of root-knot nematode (Meloidogyne spp.). Plant Pathol. 56:190-197.

Blok, V. C., Wishart, J., Fargette, M., Berthier, K., and Phillips, M. S. 2002. Mitochondrial DNA differences distinguishing Meloidogyne mayaguensis from the major species of tropical root-knot nematodes. Nematology 4: 773-781.

Chizhov, V. N., Chumakova, O. A., Subbotin, S. A., and Baldwin, J. G. 2006. Morphological and molecular characterization of foliar nematodes of the genus Aphelenchoides: A. fragariae and A. ritzemabosi (Nematoda: Aphelenchoididae) from the Main Botanical Garden of the Russian Academy of Sciences. Russ. J. Nematol. 14:179-184.

Dai, T. T., Lu, C. C., Lu, J., Dong, S. M., Ye, W. W., Wang, Y. C., and Zheng, X. B. 2012. Development of a loop-mediated isothermal amplification assay for detection of Phytophthora sojae. FEMS Microbiol. Lett. 334:27-34.

Dow, R. L., Inserra, R. N., Esser, R. P., and Langdon, K. R. 1990. Distribution, hosts, and morphological characteristics of Tylenchulus palustris in Florida and Bermuda. J. Nematol. 22:724-728.

Duan, Y. B., Ge, C. Y., Zhang, X. K., Wang, J. X., and Zhou, M. G. 2014. Development and evaluation of a novel and rapid detection assay for Botrytis cinerea based on loop-mediated isothermal amplification. PLoS One 9: e111094.

Duncan, L. W. 2005. Nematode parasites of citrus. Pages 437-466 in: Plant Parasitic Nematodes in Subtropical and Tropical Agriculture. M. Luc, R. A Sikora, and J. Bridge, eds. CABI Publishing, Cambridge, MA.

Eisenback, J. D., Reaver, D., and Ashley, J. E. 2007. First report of the nematode, Tylenchulus palustris, parasitizing peach in Virginia. Plant Dis. 91:1683.

Fu, S. J., Qu, G. G., Guo, S. J., Ma, L., Zhang, N., Zhang, S. L., Gao, S. Y., and Shen, Z. Q. 2011. Applications of loop-mediated isothermal DNA amplification. Appl. Biochem. Biotechnol. 163:845-850.

Gasser, R. B., and Newton, S. E. 2000. Genomic and genetic research on bursate nematodes: Significance, implications and prospects. Int. J. Parasitol. 30: 509-534.

Harper, S. J., Ward, L. I., and Clover, G. R. G. 2010. Development of LAMP and real-time PCR methods for the rapid detection of Xylella fastidiosa for quarantine and field applications. Phytopathology 100:1282-1288.

Heald, C. M., and O'Bannon, J. H. 1987. Citrus declines caused by nematodes. V. Slow decline. Nematol. Circ. No. 143. Florida Department of Agriculture and Consumer Services, Division of Plant Industry, Tallahassee, FL.

Huang, J. L., Liu, Z. M., Lu, X. H., and Lu, G. Y. 2011. Preliminary investigation on Tylenchulus semipenetrans of citrus in Guangxi. S. China Fruits 40:60-61.

Huang, J. L., Liu, Z. M., Lu, X. H., Qin, B. X., Ai, H. J., and Qiao, L. Y. 2012. Trial on controlling citrus Tylenchulus semipenetrans. J. South. Agric. 43: $1139-1141$

Inserra, R. N., Vovlas, N., Nyczepir, A. P., Wehunt, E. J., and Golden, A. M. 1990. Tylenchulus palustris parasitizing peach trees in the United States. J. Nematol. 22:45-55.

Inserra, R. N., Vovlas, N., O'Bannon, J. H., and Esser, R. P. 1988. Tylenchulus graminis $\mathrm{n}$. sp. and $T$. palustris $\mathrm{n}$. sp. (Tylenchulidae), from native flora of Florida, with notes on $T$. semipenetrans and T. furcus. J. Nematol. 20: 266-287.

Kikuchi, T., Aikawa, T., Oeda, Y., Karim, N., and Kanzaki, N. 2009. A rapid and precise diagnostic method for detecting the pinewood nematode Bursaphelenchus xylophilus by loop-mediated isothermal amplification. Phytopathology 99:1365-1369.

Li, Y. Q., Wang, Y., and Yu, S. P. 2001. Damage of Tylenchulus semipenetrans disease on citrus in Yunnan Province. J. Shenyang Agric. Univ. 32:236-237.

Liu, G. K., Chen, J., Xiao, S., Zhang, S. S., and Pan, D. M. 2011. Development of species-specific PCR primers and sensitive detection of the Tylenchulus semipenetrans in China. Agric. Sci. China 10:252-258.

Maafi, Z. T., Amani, M., Stanley, J. D., Inserra, R. N., Van den Berg, E., and Subbotin, S. A. 2012. Description of Tylenchulus musicola sp. n. (Nematoda: Tylenchulidae) from banana in Iran with molecular phylogeny and characterisation of species of Tylenchulus Cobb, 1913. Nematology 14:353-369.

Maafi, Z. T., Subbotin, S. A., and Moens, M. 2003. Molecular identification of cyst-forming nematodes (Heteroderidae) from Iran and a phylogeny based on the ITS sequences of rDNA. Nematology 5:99-111.

Maeda, H., Kokeguchi, S., Fujimoto, C., Tanimoto, I., Yoshizumi, W., Nishimura, F., and Takashiba, S. 2005. Detection of periodontal pathogen Porphyromonas gingivalis by loop-mediated isothermal amplification method. FEMS Immunol. Med. Microbiol. 43:233-239.

Mori, Y., Nagamine, K., Tomita, N., and Notomi, T. 2001. Detection of loopmediated isothermal amplification reaction by turbidity derived from magnesium pyrophosphate formation. Biochem. Biophys. Res. Commun. 289:150-154.

Nagamine, K., Hase, T., and Notomi, T. 2002. Accelerated reaction by loopmediated isothermal amplification using loop primers. Mol. Cell. Probes 16: 223-229.

Nickle, W. R. 1991. Manual of Agricultural Nematology. Marcel Dekker, Inc., New York.

Niessen, L., and Vogel, R. F. 2010. Detection of Fusarium graminearum DNA using a loop-mediated isothermal amplification (LAMP) assay. Int. J. Food Microbiol. 140:183-191.

Niu, J. H., Guo, Q. X., Jian, H., Chen, C. L., Yang, D., Liu, Q., and Guo, Y. D. 2011. Rapid detection of Meloidogyne spp. by LAMP assay in soil and roots. Crop Prot. 30:1063-1069.

Niu, J. H., Jian, H., Guo, Q. X., Chen, C. L., Wang, X. Y., Liu, Q., and Guo, Y. D. 2012. Evaluation of loop-mediated isothermal amplification (LAMP) assays based on 5S rDNA-IGS2 regions for detecting Meloidogyne enterolobii. Plant Pathol. 61:809-819.

Notomi, T., Okayama, H., Masubuchi, H., Yonekawa, T., Watanabe, K., Amino, N., and Hase, T. 2000. Loop-mediated isothermal amplification of DNA Nucleic Acids Res. 28:e63. 
Park, B. Y., Park, S. N., Lee, J. K., and Bae, C. H. 2009. Morphometric and genetic variability among Tylenchulus semipenetrans populations from citrus growing area in Korea. Plant Pathol. J. 25:236-240.

Peng, H., Peng, D. L., Hu, X. Q., He, X. F., Wang, Q., Huang, W. K., and He, W. T. 2012. Loop-mediated isothermal amplification for rapid and precise detection of the burrowing nematode, Radopholus similis, directly from diseased plant tissues. Nematology 14:977-986.

Powers, T. O., and Harris, T. S. 1993. A polymerase chain reaction method for identification of five major Meloidogyne species. J. Nematol. 25:1-6.

Powers, T. O., Todd, T. C., Burnell, A. M., Murray, P. C. B., Fleming, C. C., Szalanski, A. L., Adams, B. A., and Harris, T. S. 1997. The rDNA internal transcribed spacer region as a taxonomic marker for nematodes. J. Nematol. 29:441-450.

Subbotin, S. A., Ragsdale, E. J., Mullens, T., Roberts, P. A., Mundo-Ocampo, M., and Baldwin, J. G. 2008. A phylogenetic framework for root lesion nematodes of the genus Pratylenchus (Nematoda): Evidence from 18s and D2-D3 expansion segments of 28s ribosomal RNA genes and morphological characters. Mol. Phylogenet. Evol. 48:491-505.

Subbotin, S. A., Vierstraete, A., De Ley, P., Rowe, J., Waeyenberge, L., Moens, M., and Vanfleteren, J. R. 2001. Phylogenetic relationships within the cyst- forming nematodes (Nematoda, Heteroderidae) based on analysis of sequences from the ITS regions of ribosomal DNA. Mol. Phylogenet. Evol. 21:1-16.

Subbotin, S. A., Waeyenberge, L., and Moens, M. 2000. Identification of cyst forming nematodes of the genus Heterodera (Nematoda: Heteroderidae) based on the ribosomal DNA-RFLPs. Nematology 2:153-164.

Van Gundy, S. D., and Meagher, J. W. 1977. Citrus nematode (Tylenchulus semipenetrans) problems worldwide. Proc. Int. Soc. Citricult. 3:823-826.

Verdejo-Lucas, S., and Kaplan, D. T. 2002. The citrus nematode: Tylenchulus semipenetrans. Pages 207-219 in: Plant Resistance to Parasitic Nematodes. J. L. Starr, R. Cook, and J. Bridge, eds. CABI Publishing, Cambridge, MA.

Wang, Y., Yu, S. F., Li, Y. Q., Hu, X. Q., and Pu, W. Q. 2004. Studies on rDNA of Tylenchulus semipenetrans and Pratylenchus spp. by ITS-RFLP. J. Laiyang Agric. Coll. 21:151-153.

Yan, G., Smiley, R. W., Okubara, P. A., Skantar, A. M., and Reardon, C. L. 2013 Developing a real-time PCR assay for detection and quantification of Pratylenchus neglectus in soil. Plant Dis. 97:757-764.

Zhao, W. X., and Yang, B. J. 2006. A List of Plant Nematodes in China. China Forestry Publishing House, Beijing. 